\title{
A TAXONOMY FOR SELECTING GLOBAL SUPPLY CHAIN STRATEGIES
}

\author{
Martin Christopher ${ }^{1}$ Helen Peck $^{2}$ and Denis Towill ${ }^{3}$ \\ ${ }^{1}$ Cranfield School of Management, Cranfield University, Bedford, MK43 OAL \\ Telephone: 01234 754183,e-mail: m.g.christopher@cranfield.ac.uk \\ ${ }^{2}$ Defence College of Management \& Technology, Cranfield University, Shrivenham, SN6 8LA \\ Telephone: 01793 782551,e-mail: h.peck@cranfield.ac.uk \\ ${ }^{3}$ Cardiff University, Logistics Systems Dynamics Group, Cardiff Business School, Aberconway \\ Building, Colum Drive, Cardiff, CF10 3EU, Wales, UK. \\ Telephone: +44 (0)2920 876083,e-mail: ScottD1@Cardiff.ac.uk
}

\begin{abstract}
$\underline{\text { Abstract }}$
Purpose

This paper addresses the increasingly important question of supply chain design for global operations. With the rise of off-shore sourcing and the simultaneous need for improved responsiveness to customer demand, the choice of supply chain strategy is critical.
\end{abstract}

\section{Design/methodology/approach}

The paper draws its conclusions from case-based research supported by survey data.

\section{Findings}

The paper provides evidence that the choice of supply chain strategy should be based upon a careful analysis of the demand/supply characteristics of the various product/markets served by a company. It presents the basis for a taxonomy of appropriate supply chain strategies.

\section{Practical implications}

Given the increasing trend to out-sourcing and off-shore sourcing, the choice of supply chain strategy is of some significance and clearly impacts competitive performance.

\section{Originality/value}

Whilst there is a growing recognition of the need to match the supply chain to the market, there is still limited research into what criteria should be utilised to aid the 
choice of supply chain strategy. This paper attempts to extend our understanding of the issues.

\section{Research limitations}

The case studies and empirical research reported in this paper are specific to the clothing manufacturing and fashion industries and there would be benefit in extending the research into other sectors.

Keywords : sourcing strategy; lean/agile supply; supply chain taxonomy

Paper type : Research paper

\section{Introduction}

It is now increasingly accepted that "one size does not fit all" when it comes to designing supply chain strategies to support a wide range of products with different characteristics sold in a diversity of markets (Shewchuck, 1998). It has long been recognised that manufacturing strategy should be tailored to match the required 'order winning criteria' in the market place (Hill, 1985). However, this idea of aligning the firm's operations with market place requirements has not always been extended to the wider supply chain. It can be argued that sourcing strategy, operations strategy and route-to-market need to be appropriate to specific product/market conditions. In his seminal paper, Fisher (1997) drew on examples from a diverse range of consumer products, including food, fashion apparel and automobiles, to illustrate why different supply chain solutions were required depending upon whether products were 'functional' or 'innovative'. Functional products tend to have stable and predictable demand with long lifecycles. Innovative products, in contrast, generally have unpredictable demand with short lifecycles. This framework for supply chain design has been further developed by Christopher $\&$ Towill (2002) through the addition of replenishment lead-time as a critical driver of supply chain strategy.

Today's market place is characterised by heightened global competition often against a backdrop of an excess of supply over demand. In such situations there is a danger, due to the continual pressure to take out costs that sub-optimal supply chain decisions may be taken. For example, the introduction of 'just-in-time' delivery may reduce inventory in the factory but increase it at the supplier whilst also increasing transport costs. What might look like a cost saving to one firm could mean increased costs to the supply chain as a whole.

To avoid this type of sub-optimisation a holistic approach to supply chain management (SCM) should be adopted. Since it is argued that "supply chains compete, not companies" (Christopher, 1992) this implies the existence of a climate wherein holistic SCM is possible. Indeed an early move in this direction was proposed by Kraljic (1983) when arguing that purchasing needed to be seen in the 
perspective of the wider supply chain. By definition, supply chain management demands a high level of 'joined-up thinking'. In other words the selection of suppliers, the location of facilities and the choice of distribution channels should all be driven by the goal of enabling the marketing objectives of the organisation to be achieved. In the ideal world, supply chains would be designed from the 'customer backwards' rather than the conventional approach which tends to be from the 'factory outwards'. The temptation is to create supply chains which are more focused upon 'efficiency' goals than 'effectiveness' goals. Thus the typical supply chain strategy is likely to be aimed at achieving a smooth flow at minimum cost (Harrington, 1991 and Scott and Westbrook, 1991). But how are the right supply chain decisions to be made which will enable the defined business and marketing strategy to be enacted? How does the in-sourcing/out-sourcing option fit into the holistic scheme of things? Is there a taxonomy which executive management may use with confidence to establish not only the type, but the number of segmented supply chain strategies required? This paper provides some possible answers to these questions.

\section{THE RISE OF GLOBAL SOURCING}

Over the last twenty years, geopolitical events moving in step with technological developments and the deregulation of trade have made global sourcing and supply a reality. The old norms of 'local for local' manufacturing and sourcing have been swept away, apparently opening the door to the 'global village'. The lure of cost savings, largely due to fewer regulatory controls and significantly lower wages has prompted the mass-migration of manufacturing from the developed world to emergent economies in other regions. China has become the favoured destination for manufacturing industry of all kinds. In fact its emergence as a force in international trade, after decades of isolationism, has been one of the most remarkable phenomena of recent years. In the 1990s, its trade grew three times faster than that of the global economy, and while world trade stagnated between 2000 and 2002, its imports and exports rose by $30 \%$ (WTO 2003).

The paradox is that supposedly low-cost off-shore sourcing strategies can end up as high-cost supply chain outcomes. The reasons behind this are often complex, but some seemingly obvious factors are often overlooked. First there are higher transport costs, due in part to the greater distances covered. Geopolitics is a factor here too. East-West trade has benefited for many years from relatively low transport costs, underpinned by stable oil prices. The uncertainty in oil markets before and after the US-led invastion of Iraq in 2003, raised questions about the longer-term viability of globe-spanning supply chains and the underlying assumptions of prevailing purchasing practices (New 2003). With more and more manufacturers heading for China, shipping prices have risen sharply and seasonal shortages in freight capacity have emerged (Johnson 2001).

The second, and less obvious cost driver is the extension in lead-times, resulting from distance and the almost inevitable complications involved in coordinating 
shipments from far-off suppliers, through forwarders, shippers, customs and delivery networks. Often this requires the ability to manage across diverse cultural, legal and regulatory environments.

For many so-called 'commodity' items the lower manufacturing costs may well outweigh the higher costs of transport and the longer lead times. For other categories of products, particularly those identified by Fisher (1997) as innovative, this may not be the case. Electronics manufacturer Sony found this to be so with its high-tech camcorders and digital cameras. In 2002 it moved production of both from China to Japan. The reason for Sony's decision was supply chain cost-related (Bin 2003). China had proved to be an excellent location for many of Sony's less innovative competitors who focussed on the forecast-driven, efficient production of products based on proven technologies. But for its leading edge products, Sony found that China's manufacturing base lacked critical 'market mediation' capabilities - i.e.the technological expertise, benefits of proximity and the supply chain flexibility to cope with the demands of high-margin, high-risk new product introductions

Companies that choose to differentiate themselves through innovation must tread the fine line between the dangers of over-optimistic forecasting with the attendant risks of remaindered stock, and the risks of wasted opportunity arising from the inability to supply quickly enough when a winning product is produced. To survive they must be able to minimise the risk from failed products and maximise the benefits of successful innovations, before margins fall as competitors follow with cheaper, less risky, 'me-too' offers. Sony had managed the inherent risks of innovative new product introductions through close collaboration between itself and its suppliers throughout the new product development process. The networks of suppliers had the capabilities to respond very rapidly to consumer demand should the product prove to be successful in the market. Sony relocated its leading edge product production from China because its efficient low-cost manufacturers lacked these essential capabilities, but the skills were well-established and available - at a cost - in Japan. Added to this was the fact that while demand for consumer electronics is strong in China, most of the customers for the high margin innovative products are in the more developed markets of the US, Western Europe and Japan. Consequently, Japan provided a better base in terms of user market proximity, hence Sony's decision to relocate.

The pattern of trade and demand affecting other categories of consumer products is similar to that of consumer electronics. In 2002, the value of clothing exports worldwide reached $\$ 200$ billion, accounting for around $3.2 \%$ of all merchandise exports by value. Again the US, Western Europe and Japan are the main importers accounting for around $80 \%$ of all clothing imports. Amongst the major suppliers to the EU were China, Turkey and Romania, each expanded their shipments to the EU by between $15 \%$ and $22 \%$ in 2002 . China also increased its imports to the US and continued to supply more than three quarters of clothing imported to Japan (WTO 2003). The challenge to business organisations that seek to improve their competitiveness in this sector too is to find the supply chain solution that best fits the 
demands of the market place. In this paper we will examine in more detail the circumstances where global sourcing is advantageous, and situations where the imperative is for shorter, more responsive supply chains.

\section{Pipeline lead-times}

In many markets, time has become a competitive variable. Not just time-to-market for new product introductions but time-to-respond in terms of being able to meet the needs of time-sensitive customers. Nowhere is this more true than in the apparel industry where seasons can be short and demand unpredictable. Paradoxically in this industry lead-times have if anything lengthened over the last decade or so. This is primarily the result of global sourcing as retailers have sought out low cost sources of supply. The risk that is incurred through lengthened lead-times can be considerable. If decisions on style, colour and quantity have to be taken many months ahead of the season then the greater is the chance of error in the forecast. As a rule of thumb (Blackburn, 1991) forecast errors in the fashion industry related to the forecast time horizon are as follows:-

- Start of season $\pm 10 \%$

- Minus 16 weeks $\pm 20 \%$

- Minus 26 weeks $\pm 40 \%$

Nor is the situation any better in consumer electronics (Watson, 1993) where the equivalent rule of thumb is:

- Forecast 1 month ahead $\pm 5 \%$

- Forecast 2 months ahead $\pm 20 \%$

- Forecast 3 months ahead $\pm 50 \%$

It has been suggested (Lowson, 2001) that for the UK garment retail industry the move to offshore sourcing can quadruple the time from order to delivery in some cases thus dramatically increasing supply chain risk.

Whilst the purchase cost of the garment is clearly significantly less if sourced from, say, the Far East this comes at the expense of lack of flexibility to both order mix and volume change, plus long lead times, as Table 1 shows (Christopher and Towill, 2002). Here we have computed integrated responsiveness metrics from survey data from the clothing industry obtained by Lowson (2001). The Table provides a simple method of ranking the flexibility of these various sources. Thus the European vendors perform very much better responding to pre-season changes compared to Asia. This advantage also carries over into flexibility of supply after the season has started. Additionally, if the lead times are compared with the previously quoted forecast errors (say 16 weeks out) then it is clear that matching supply with demand is greatly affected by the long lead times associated with some offshore sources. So a business operating in such a scenario and supplied via a single delivery pipeline 
can expect to have many stock-outs alternating with huge surpluses, and seasonal sales at knock down prices. All these factors heavily erode profit margins.

Table 1 - Estimate of Vendor Responsiveness to Volume Change and Mix Change According to Geographic Region

(Source: Authors based on European Survey results Undertaken by Lowson, 2001)

\begin{tabular}{|c|c|c|c|c|c|}
\hline \multirow{3}{*}{$\begin{array}{l}\text { Sourcing } \\
\text { Region }\end{array}$} & \multirow{3}{*}{$\begin{array}{l}\text { Order-to- } \\
\text { Delivery } \\
\text { Lead Time } \\
\text { (Weeks) }\end{array}$} & \multicolumn{4}{|c|}{ Computed Response Metric (Higher is Better) } \\
\hline & & \multicolumn{2}{|c|}{$\begin{array}{l}\text { Before Start of } \\
\text { Season }\end{array}$} & \multicolumn{2}{|c|}{ After Start of Season } \\
\hline & & $\begin{array}{l}\text { Volume } \\
\text { Change }\end{array}$ & $\begin{array}{c}\text { Order } \\
\text { Mix }\end{array}$ & $\begin{array}{l}\text { Volume } \\
\text { Change }\end{array}$ & $\begin{array}{c}\text { Order } \\
\text { Mix }\end{array}$ \\
\hline North America & 35 & .34 & .23 & .28 & .26 \\
\hline European & 12 & .57 & .48 & .30 & .15 \\
\hline Non-EU & 21 & .42 & .37 & .49 & .46 \\
\hline $\begin{array}{l}\text { Central } \\
\text { America }\end{array}$ & 38 & .16 & .11 & .25 & .17 \\
\hline Asia & 55 & .19 & .17 & .15 & .06 \\
\hline Africa & 39 & .29 & .24 & .21 & .21 \\
\hline Other & 34 & .40 & .46 & .39 & .35 \\
\hline
\end{tabular}

\section{Lean and Agile Supply Chains}

One of the more interesting debates in recent years concerning supply chain strategy has centred around the relative merits of 'lean' and 'agile' philosophies. The idea of 'lean thinking' has been expounded by Womack and Jones (1996) amongst others. The focus of lean thinking has been on the reduction or elimination of waste (muda). The origins of the lean approach can be traced to the Toyota Production System (TPS) with its focus on the efficient use of resources through level scheduling (Ohno, 1988). It has been suggested (Christopher, 2000) that lean concepts work well where demand is relatively stable and hence predictable and where variety is low. Conversely in those contexts where demand is volatile and the customer requirement for variety is high, a different approach is called for.

This is the concept of 'agility'. Agility is concerned primarily with responsiveness. It is about the ability to match supply and demand in turbulent and unpredictable markets. In essence it is about being demand-driven rather than forecast-driven.

Agility is a business-wide capability that embraces organisational structures, logistics processes and, in particular, mind-sets. A key characteristic of an agile organisation 
is flexibility. Indeed, the origins of agility as a business concept lie in flexible manufacturing systems (FMS). Later this idea of manufacturing flexibility was extended into the wider business context (Nagel \& Dove, 1991) and the concept of agility as a supply chain philosophy was born.

In reality the two approaches can complement each other, and in many cases there is a requirement for a "hybrid" lean/agile strategy to be adopted, (Christopher and Towill, 2000). Hence it is our contention that the issue is not "Lean versus Agile" rather it is the judicious selection and integration of appropriate aspects of these paradigms appropriate to the particular supply chain strategy. In some cases the two ideas of lean and agile can be brought together as a hybrid 'leagile' solution (Naylor et.al. 1999)

One such 'hybrid' solution is to utilise lean principles when designing supply chains for predictable standard products and agile principles for unpredictable or 'special' products. Or again it may be that total demand for a product can be separated as 'base' and 'surge' demand. Base demand is more predictable and less risky so lean principles can be applied, using agile approaches to cope with surge demand. An example of this separation of base and surge demand is the multiple pipeline solution implemented by the Griffin Manufacturing Co. (Stratton and Warburton, 2001). Their approach is shown in Table 2, and seeks an optimal blend of in-sourcing and out-sourcing in meeting both baseline and surge demands. In 1999 the resulting balance worked out at $80 \%$ production in Honduras, and $20 \%$ production in the USA. 
Table 2 - Pragmatic Multiple Pipeline Solution Adopted by Griffin Manufacturing Co.

(Source: Authors Based on Stratton and Warburton, 2001)

\begin{tabular}{|c|c|c|c|c|c|}
\hline \multirow{2}{*}{$\begin{array}{l}\text { Griffin } \\
\text { Manufacturing } \\
\text { Pragmatic Solution }\end{array}$} & \multirow[b]{2}{*}{$\begin{array}{l}\text { Pipeline } \\
\text { Purpose }\end{array}$} & \multirow[b]{2}{*}{ Supplier } & \multicolumn{3}{|c|}{ Pipeline Characteristics } \\
\hline & & & Product & Demand & $\begin{array}{l}\text { Lead } \\
\text { Time }\end{array}$ \\
\hline $\begin{array}{l}\text { High Volume } \\
\text { Lean Pipeline }\end{array}$ & $\begin{array}{l}\text { Baseline } \\
\text { Demand }\end{array}$ & Out-Sourced & Standard & Stable & Long \\
\hline $\begin{array}{l}\text { Top-Up } \\
\text { Agile Pipeline }\end{array}$ & $\begin{array}{l}\text { Surge } \\
\text { Demand }\end{array}$ & In-House & Standard & Volatile & Short \\
\hline $\begin{array}{l}\text { Innovative Goods } \\
\text { Agile Pipeline }\end{array}$ & $\begin{array}{l}\text { Surge } \\
\text { Demand }\end{array}$ & In-House & Special & Volatile & Short \\
\hline
\end{tabular}

It is also likely that products may well require different kinds of pipeline according to their position within the product life cycle (Christopher and Towill, 2000).

So pipelines should not be fixed for all times. What is needed is a continuous assessment of the product range and market characteristics so that changing scenarios may be identified. Against these product/market characteristics will be a number of alternative options for pipeline design, heavily dependent upon supply lead times. So it is not surprising that lead times form a major part of our supply chain taxonomy.

\section{A Taxonomy for Pipeline Selection}

A number of classification schemes have been proposed in the literature to guide the choice of supply chain strategy (e.g. Fisher, 1997, Childerhouse, 2002). Because of the critical impact that replenishment lead-times have on responsiveness to demand and because, as we have observed, globalisation is tending to extend those leadtimes, we believe that lead-time must be included in any useful taxonomy. Thus we are suggesting a simple three-dimensional classification appropriate for global supply chains. The dimensions and their binary gradations are:-

- Products (standard or special)

- Demand (stable or volatile)

- Replenishment lead-times (short or long)

Hence there will be eight $(2 \times 2 \times 2)$ theoretical pipeline types. In practice some of these are either unlikely to be encountered or are non-viable situations.

Whilst the characterisation of products as either 'special' or standard' may be an over-simplification it is a useful high-level distinction. What makes a product 'special' in our sense is probably that it is either low volume with erratic demand or it is a product with a probable short life cycle or, possibly, a product with a high level 
of customisation. 'Standard' products on the other hand will tend to be more stable in demand with longer life cycles with no, or limited, customisation.

Because predictability and product type will tend to be related, i.e. standard products will be more predictable (at least over longer periods), it is possible to simplify the taxonomy into just two dimensions : predictability and replenishment lead-times.

Figure 1 summarises the resulting 2x 2 matrix and Table 3 defines the four suggested pipeline solutions that emerge from the classification.

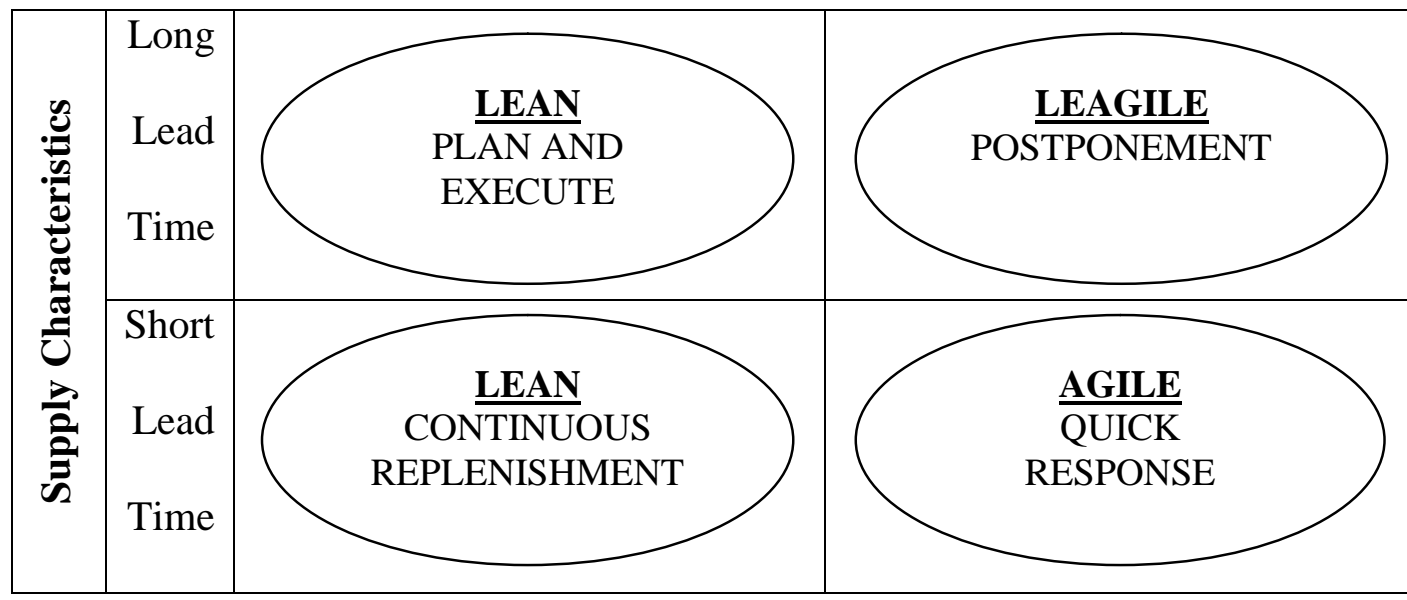

\section{Predictable Unpredictable \\ Demand Characteristics}

Figure 1 - How Demand/Supply Characteristics Determine Pipeline Selection Strategy

(Source: Authors)

On the horizontal axis of Fig. 1 we show the demand characteristics in terms of 'predictability'. This is likely to be determined by the variability of demand, hence measures such as the Coefficient of Variation $(\sigma / \bar{x})$ could be used to position products on that axis. The vertical axis reflects the replenishment lead times for the same product. Effectively this is measuring the time it would take the system to respond to an increase in demand if materials etc. had to be sourced or manufactured. If this elapsed time is measured in months rather than days then that product could be regarded as having a long re-supply lead time. 
Table 3 - Relating Pipeline Types to Supply/Demand Characteristics

\begin{tabular}{|c|c|}
\hline Supply Demand Characteristics & Resulting Pipelines \\
\hline $\begin{array}{l}\text { - Short Lead Time + Predictable } \\
\text { Demand }\end{array}$ & - Lean Continuous Replenishment \\
\hline $\begin{array}{l}\text { - Short Lead Time + Unpredictable } \\
\text { Demand }\end{array}$ & - Agile Quick Response \\
\hline $\begin{array}{l}\text { - Long Lead Time + Predictable } \\
\text { Demand }\end{array}$ & - Lean, Planning and Execution \\
\hline $\begin{array}{l}\text { - Long Lead Time + Unpredictable } \\
\text { Demand }\end{array}$ & $\begin{array}{l}\text { - Leagile Production/ Logistics } \\
\text { Postponement }\end{array}$ \\
\hline
\end{tabular}

As outlined above, the matrix suggests that there might be four possible generic supply chain strategies. In those situations where demand is predictable and replenishment lead-times are short then a 'continuous replenishment' strategy may be appropriate. This is how companies like Procter \& Gamble manage their supply chain for volume products to Wal-Mart in the USA. Making use of point-of-sale data they can rapidly replenish individual stores through a process of Vendor Managed Inventory (VMI).

At the other extreme (unpredictable demand and long lead-times) the ideal solution is to carry strategic inventory in some generic form and assemble/configure/distribute as required when actual demand is encountered. This is the classic 'postponement' concept. Hewlett Packard follow this strategy for their range of DeskJet printers. They build a semi-finished product at their central facilities in North America and then ship it to four regional centres around the world which are run for them by thirdparty logistics service providers. At these centres the product is finally configured and delivered when actual customer orders are received.

If lead-times are long but demand is predictable, then there is opportunity for the pursuit of 'lean' type strategies, e.g. make or source ahead of demand in the most efficient way. An example is provided by the UK retailer Woolworths. Woolworths sell a million plastic Christmas trees each year. They source these mainly from China and have to place their order over six months ahead of the season. However, they see little risk in this strategy given their prior experience of demand for the product.

Finally, when demand is unpredictable but lead-times are short, then agile solutions will be required based upon rapid response. A good example of agility is the case of Zara, the Spanish fashion garment manufacturer and retailer. They can move products into their stores across Europe in as little as three to four weeks after they have been designed. They do this by using cross-functional teams to manage the end-to-end process and by using numerous small workshops in Spain and Portugal to give them a high level of flexibility. 
Within each cell of the matrix the tactics adopted may also be influenced by whether the product is 'standard' or 'special'. For example, in the 'postponement' cell of Figure 1, for a special product we may postpone manufacture, but for a standard product it may be better to postpone distribution (Pagh and Cooper, 1998).

Finally, to underline the importance of choosing the right supply chain strategy depending upon the supply and demand characteristics encountered, we briefly describe the dilemma facing the British retailer, Marks \& Spencer. This case study suggests that the company may have initially failed to recognise the need to adopt different supply chain strategies for their 'special', more fashion-oriented products, and their 'standard', stable demand items.

\section{SELECTING GLOBAL PIPELINES - AN APPAREL INDUSTRY CASE STUDY}

Marks \& Spencer $(M \& S)$, a major British retailer, had long been a textbook example of a successful extended enterprise. For decades it had been an industry leader in collaborative working with its network of dedicated local suppliers. In the 1990s it abandoned its UK sourcing strategy, first by requiring its established suppliers to relocate production overseas to low cost manufacturing centres, then to more open sourcing policies. This change in strategy was forced upon it by competitive pressures, particularly the continuing downward pressure on price. To maintain profitability, M\&S were forced to seek a step change in cost-reduction.

The potential for cost reduction through this means was dramatic, at least on paper. According to the British Apparel and Textile Confederation, the average hourly labour cost for clothing manufacturers in the UK in 2000 was $\$ 9.50$ compared to $\$ 1.20$ an hour in Morocco and less than 50 cents an hour in China, Pakistan and Indonesia. M\&S soon discovered that this simplistic calculation failed to take into account the hidden costs of overseas sourcing, particularly the risks relating to significantly extended replenishment lead-times. It overlooked the need to secure transport capacity and textile import quotas ahead of season, discovering too late that it lacked the essential logistics know-how needed to support its new sourcing strategy.

Whereas M\&S's dedicated domestic suppliers had been able to re-supply relatively rapidly, with overseas sourcing orders typically had to be placed many months ahead of requirement. Inevitably, reliance on forecasts increased. Thus buyers had to forecast styles, colours and volumes well ahead of the season. If these forecasts were wrong - and they often were - then the result was either over-stocking or a stock-out. Either way, this had a negative impact on profitability. Indeed one of the major causes of the M\&S profit slump in the late 1990s was the lack of interest shown by consumers in the M\&S clothing range where the buyers had seriously misjudged fashion trends. 
Part of the problem for M\&S was that their definition of cost was too narrow, i.e. the purchase cost rather than the total cost of ownership. In the event, what was intended to be a low cost supply chain solution turned out to be high cost, not least because they had adopted a 'one size fits all' supply chain strategy for their clothing products. It could be argued that the strategy would have been, and indeed is appropriate for high volume 'standard' items, such as men's shirts and socks, but not for 'innovative' or 'special' ranges such as M\&S's exclusive short-life cycle, designerled, high margin Autograph range.

It is now acknowledged amongst the top management team at M\&S that a much more differentiated supply chain strategy for garments is essential. The new supply chain strategy was first outlined in M\&S's Interim Report of September 2002 when the Chairman and Chief Executive wrote:-

"Lack of flexibility has been the major weakness within our supply chain. In the past, we bought stock to cover 100\% of budgeted sales well in advance of the season. We have now discontinued this practice. For Spring 2001, while 50\% of merchandise is core and therefore bought with long lead-times, we will commit to approximately $40 \%$ of merchandise much closer to the season, and a further $10 \%$ will be bought in the season itself in response to emerging fashion trends."

Degree of predictability of demand and the length of the season are factored in to sourcing decisions. These issues increasingly determine where products should be sourced, how they should be transported and whether it is a one-off buy or a continuing supply.

In spring 2004, $80 \%$ of clothing sourced by M\&S was manufactured overseas, though it retains close relationships with its leading suppliers, with its top 15 suppliers accounting for $92 \%$ of its clothing business. Many of these are UK-owned companies operating overseas, in up and coming Asian countries such as Cambodia as well as some of the new EU Accession States. 'Journey time' has become a principal deciding factor in product sourcing decisions. The emphasis is on quick response for lines where demand is difficult to predict. These items are manufactured in locations with a journey time of less than four days. Standard items, for which demand is expected to be predictable and continuous, continue to be sourced from low cost centres around the globe.

$M \& S$ is acknowledged to be getting better at managing sourcing and replenishment issues, though it continues to struggle to align its standard product offer with the evolving tastes in the market (Warner 2004). The problem emphasises the point that a responsive supply chain can minimise the risks associated with unappealing products, but cannot overcome poor design and buying decisions which fail to introduce attractive products in the first place.

\section{Conclusions}


As global sourcing and offshore manufacturing dramatically alter the landscape of business activity, there needs to be a similar change in the way in which supply chain strategies are determined. Whilst downward pressure on price will continue to be a real issue in deflationary market conditions, it also has to be recognised that agility and responsiveness are increasingly fundamental to competitive success.

In this paper we have proposed a taxonomy to guide the selection of appropriate global supply chain strategies. The key dimensions of this taxonomy are replenishment lead-times and predictability/variability of demand. Whilst previous taxonomies have tended to focus on the nature of the product and its life cycle, we suggest that these can be further enriched by the use of lead-time and demand variability measures.

The challenge to today's global business is firstly to identify the appropriate supply chain solutions to meet the different needs of the different product/market characteristics and then secondly to manage what are likely to be multiple supply chains.

\section{REFERENCES}

Bin, J. (2003), "What pulled Sony out of China?", Supply Chain Management Review, January/February, pp22-27

Blackburn, J.D. (1991), "The Quick-response Movement in the Apparel Industry: a Case Study in Time Compressing Supply Chains”, in Blackburn, J.D. (Ed) Time Based Competition, Business One Irwin, Homewood, pp. 246-269.

Childerhouse, P. (2002), Enabling Seamless Market-Orientated Supply Chains, PhD Thesis, LSDG, Cardiff University.

Childerhouse, P., Aitken, J., and Towill, D.R. (2002), "Analysis and Design of Focussed Demand Chains”, Journal of Operations Management, No. 20, Issue 6, pp. 675-689.

Christopher, M., (1992), Logistics and Supply Chain Management: Strategies for Reducing Costs and Improving Services, Pitman Publishing, London.

Christopher, M., (2000), "The agile supply chain : competing in volatile markets", Industrial Marketing Management, Vol. 29, No. 1, pp 37-44

Christopher, M. and Towill, D.R. (2002), "Developing Market Specific Supply Chain Strategies", International Journal of Logistics Management, Vol. 13, No. 1, pp. 1-14.

Christopher, M. and Towill, D.R. (2000), "Marrying the Lean and Agile Paradigms" Proc. EUROMA Conference, Ghent, pp. 114-121.

Fisher, M., (1997), "What is the Right Supply Chain for your Product?" Harvard Business Review, March/April, pp. 105-116.

Fisher, M.L., Hammond, J.H., Obermeyer, W.R., Raman, J., (1994), "Making Supply Meet Demand in an Uncertain World”, Harvard Business Review, May-June, pp 83-93. 
Harrington, H.J. (1991), Business Process Improvement, McGraw-Hill, New York.

Hill, T. (1993), Manufacturing Strategy : Text and Cases, Second Edition, MacMillan Press, London.

Johnson, M.E. (2001) "Learning From Toys: Lessons in Managing Supply Chain Risk From the Toy Industry”, California Management Review, Vol.43, No.3, Spring, pp106-124.

Kraljic, P. (1983), "Purchasing Must Become Supply Chain Management", Harvard Business Review, Sept/Oct, pp. 109-118.

Lee, H.L., Padmanabhan, V. and Whang, S. (1997), "Information Distortion in a Supply Chain: The Bullwhip Effect”, Management Science, Vol. 43, No. 4, pp. 546-558.

Lowson, R. (2001), “Analysing the Effectiveness of European Retail Sourcing Strategies”, European Management Journal, Vol. 19, No. 5, pp. 543-551.

Mason-Jones, R., Naylor, J.B. and Towill D.R. (2000), "Lean, Agile or Leagile? Matching Your Supply Chain to the Marketplace" International Journal of Production Research, Vol. 38, No. 17, pp. 4061-4070.

Naylor, J.B., Naim, M.M. and Berry, D., (1999), "Leagility: Interfacing the Lean and Agile Manufacturing Paradigm in the Total Supply Chain", International Journal of Production Economics, Vol. 62, pp. 107-118.

Nagel, R. \& Dove, R., (1991), $21^{\text {st }}$ Century Manufacturing Enterprise Strategy, Lehigh University, Incocca Institute.

New, S. (2003) “There May be Troubles Ahead”, Supply Management, $2^{\text {nd }}$ January, pp16-19

Ohno, T., (1988), The Toyota Production System : beyond Large Scale Production, Productivity Press, Portland, OR

Pagh, J.D. and Cooper, M.L. (1998) "Supply Chain Postponement and Speculation Strategy: How to Choose the Right Strategy”, Journal of Business Logistics, Vol. 19, No. 2, pp 13-33.

Samli, A.C., Browning, J.M. and Busbia, C. (1998), "The Status of Global Sourcing as a Critical Tool of Strategic Planning Opportunistic Versus Strategic Dichotomy”, Journal of Business Research, Vol. 43, pp. 177-187.

Scott, C. and Westbrook, R. (1991) "New Strategic Tools for Supply Chain Management" International Journal of Physical Distribution and Logistics Management, Vol. 20, No. 1, pp. 23-33.

Shewchuck P. (1998), “Agile Manufacturing : One Size Does Not Fit All”, Proceedings of the International Conference on Manufacturing Value Chains, Troon, pp. 143-150.

Siekman, P. (2000), "New Victories in the Supply Chain Revolution”, Fortune, October 30.

Stratton, R, and Roy Warburton, D.H. (2001), "Systematic innovation and the strategic integration of agile and lean supply, theory and practice". Proceedings ICPR 16, Prague, Paper No. A.8.6.

Towill, D.R. and Christopher, M. (2001), “The Supply Chain Conundrum to be Lean or Agile or to be Lead and Agile" Proceedings of the International Logistics Symposium, Salzburg, pp. 3-12. 
International Journal of Logistics Management, Vol. 17, No. 2, 2006, pp 277-287

Warner, J. (2004) “What Next for Marks \& Spencer, as Recovery Strategy Falters?”, The Independent, January $15^{\text {th }} \mathrm{p} 23$.

Watson, G.H. (1994) Business Systems Engineering: Managing Breakthrough Changes for Productivity and Profit, John Wiley and Sons, Inc. NY

WTO (2003) World Trade Statistics, World Trade Organization, www.wto.org. 